\title{
The Effects of Poverty Reduction Strategies on Artisanal Fishing in Ghana: The Case of Keta Municipality
}

\author{
Peter Mawunyo Dzidza ${ }^{1}$, Ian Jackson ${ }^{1}$, Ametefee K. Normanyo ${ }^{2} \&$ Michael Walsh ${ }^{3}$ \\ ${ }^{1}$ Business School, Staffordshire University, United Kingdom \\ ${ }^{2}$ Faculty of Applied Social Sciences, Ho Technical University, Ghana \\ ${ }^{3}$ Faculty of Health Science and Sports, University of Stirling, United Kingdom \\ Correspondence: Peter Mawunyo Dzidza, Business School, Staffordshire University, United Kingdom. Tel: \\ 44-78-7806-5802. E-mail: dzidza70@gmail.com
}

Received: February 1, 2017

doi:10.5539/jsd.v10n3p68
Accepted: March 22, 2017 Online Published: May 31, 2017

URL: https://doi.org/10.5539/jsd.v10n3p68

\begin{abstract}
This paper assesses the level of poverty in Ghana after three decades of successive implementation of numerous poverty reduction strategies including Structural Adjustment Program (SAP) by various governments of Ghana. The Keta municipality in the Volta region, where artisanal fishing thrives, was chosen as a representative sample of the whole country. The authors identified eleven artisanal fishing communities in the selected area using systematic sampling. Data were collected on household consumption patterns. This process was used to determine the profile of poverty using the latest upper poverty line of Ghana and the Greer and Thorbecke (1984) poverty formula. Research findings show that the various poverty alleviation methods implemented over three decades by the Government of Ghana, the World Bank, and the International Monetary Fund (IMF) significantly failed as they have not produced any meaningful effect on poverty reduction in the sample area. Finally, this paper offers further suggestions regarding how this poverty gap may be bridged using alternative methods.
\end{abstract}

Keywords: poverty, poverty reduction and fishing communities

\section{Introduction}

The relatively poor economic performance of many Sub-Saharan African (SSA) countries after implementing the Structural Adjustment Programs (SAP) recommended by the International Financial Institutions (IFI) has confounded many economists, (Franz, et al, 2011). Indeed, statistics indicate that over the past three decades, the performance of economic growth in Africa has been unequal. A general downward trend took place in most countries while others like Chad, Liberia, Mauritania, Niger, Sierra Leone, and Zaire stagnated with a growth rate of 1\% (Fosu, 2000: Zamfir, 2016). The situation in Ghana is no different. Despite being endowed with many natural resources such as gold, diamond, manganese and a large deposit of hydrocarbon, as this study demonstrates, the country is considered among one of the poorest nations in the world.

Notwithstanding Ghana's poor economic performance over the years, many Ghanaians experienced relief in November 2010. At that time, their ambition to become a middle-income country, a pursuit spanning three decades which required signing onto many IMF and the World Bank poverty reduction programmes, finally was achieved through a gross domestic product (GDP) rebasing exercise that recalculated the official GDP per capita of Ghana as 1,363 USD (Todd Moss et al., 2012). The country then recorded a GDP growth rate of $6.1 \%$ and GDP per capita at 1,966 USD in 2013.

Despite the progress made in terms of growth and development as indicated above, the United Nations Development Programme (UNDP), noted for its highly- rated, multidimensional method to measure poverty by using the Human Development Index (HDI), provides a different view. In 2012, they ranked Ghana 135 out of the 186 poorest countries in the world with an HDI value of 0.558 (UNDP, 2013). UNDP's assessment has been accepted as an accurate report of the nation's economic status. Poverty has been long-plagued Ghana. Its effect on living standards in the rural savannah remains high with approximately $86 \%$ of the total population living below the poverty line in the rural areas of Ghana (GSS, 2007).

Based on the above debate, this paper investigates whether the numerous poverty reduction strategies adopted and implemented by the various governments of Ghana since 1983 have made any impact on the lives of 
Ghanaians, especially the rural dwellers in Ghana. The article focuses on the Keta municipality in the Volta region, chosen as a representative sample of the nation. Section 2 briefly describes efforts of various governments in poverty reduction in Ghana. Section 3 reviews the literature on poverty. The fourth section explains the methodology used. Section 5 presents the results and discussion. Finally, Section 6 summarizes and concludes the study.

\section{Efforts of Poverty Reduction by Various Governments in Ghana}

In 1957, Ghana was considered as the "Black Star" of Africa and the first country in Sub-Saharan Africa to gain political independence. Indeed, its economy also was seen as the strongest with a very high per-capita income and an average income similar to that of Mexico and South Korea. As a leading producer of cocoa, the second largest producer of gold, timber and forest products, the economy of Ghana appeared relatively buoyant with growing output, a low inflation (of less than $1 \%$ ) and large accumulated external reserves.

Compelling evidence indicates that by the end of 1983, Ghana's buoyant economy bequeathed by the colonial government experienced problems. The debt stock equaled US $\$ 1,820$ billion, and inflation reached its crescendo at an all-record high of 123\% (Economic Commission for Africa, 2003). The political instability in the 1970s resulted in brain drain of both skilled and unskilled workforce to Europe, Australia, and the United States. The majority immigrated to Nigeria in order to take advantage of the emergent petro-chemical industry. The 1974 drought, coupled with the 1973-1974 and 1979-1980 global recessions, had an adverse, cumulative effect on Ghana's economy, resulting in a severe famine, unprecedented in the history of the country.

Political analysts at this time believed that the socialist revolutionary policies of the Provisional National Defense Council (PNDC) finally pushed Ghana's economy into a comatose state, leading to chronic shortages of food, mass poverty, and astronomical inflation. The 1982-83 drought in Sub-Saharan Africa compounded the economic problem, leading to widespread bushfires that caused unprecedented hunger in the sub-region. Consequently, the Shehu Shagari government of Nigeria in 1983 issued a deportation order which repatriated undocumented Ghanaian nationals to Ghana. This added 1.5 million Ghanaians to the existing population of about 12 million. These developments caused the shortage of basic amenities and essential goods such as toilet roll, water, milk, and bread (Boafo-Arthur, 1999b). This development pushed the real industrial GDP growth rate to minus $20 \%$.

The Ghanaian military government swiftly reacted to the poor economic situation by sending emissaries to its communist allies in Cuba, China, and the former Union of Soviet Socialist Republics (USSR) for help. Unfortunately, these countries could not help but advised Ghana to turn to the IMF and the World Bank for a possible economic bailout. With the above statistics and the failure of the communist allies of the government to help solve the economic problems, the Rawlings PNDC government in April 1983 (despite its initial populist stance) had no choice. They embarked on a project for economic austerity and adopted the SAP required and supported by the IMF and the World Bank.

In essence, SAP is an economic policy of the International Financial Institutions that developing countries must adopt in order to qualify for new World Bank and IMF loans. It was believed in many quarters that this measure would help such countries repay debts owed to commercial banks, governments, and the World Bank (World Bank, 2005). The policies enshrined in the SAP for individual countries have common guiding principles and features. These include an export-led growth, efficiency of the free market, devaluation of the local currency, rising of interest rates, downsizing of the public service, privatizing of public enterprises, and drastically cutting back on government expenditure on education, health, housing, and agriculture (Rothchild, 1991b).

Three decades after the adoption of SAP in Ghana, patterns emerged. Its implementation coincided with the decline in agricultural production, resulting in poverty and inequality among people in the agricultural sector, especially in the rural areas (Mosley at al. 1995 and Easterly 2000, cited in Klasen, 2003). This negative backlash regarding agriculture is intriguing. This sector's contribution to Ghana's GDP growth has been invaluable over the years, but has continued dwindling at a time when Ghanaians expected the long-term benefits of SAP (GSS, 2012). For instance, the contribution of agriculture to Ghana's GDP dropped from a pick of 57.9\% in 1980 (just before the implementation of SAP) to $25.6 \%$ in 2011 (three decades after the adoption of SAP) (GSS, 2012)

Indeed, the concern for Ghanaians is confirmed when one compares the percentage contribution of the agricultural sector to that of the services sector, which contributed about $30.2 \%$ to GDP in 1980 . This quota increased to about $49.5 \%$ in 2013.

The low contribution of agriculture to the GDP was unexpected, especially when considered within the context of the huge agricultural potential that exists in each of the agricultural sub-sectors in Ghana. Indeed, the agricultural sector is made up of five main sub-sectors, namely, forestry, cocoa, livestock, crops and fisheries. And each of the 
sub-sectors plays an important role in the socio-economic development of the country (MOFA, 2011). For instance, in 2011, the crop sector contributed about $66.2 \%$ to the agricultural GDP with the fisheries contributing $7.3 \%$. The rest are food and cash crop (19.3\%), livestock (1.8\%), forestry and logging $(2.8 \%)$ and the sector as a whole employs about $60 \%$ of the Ghanaian population (GSS, 2012). The continued decline of the agricultural sector's contribution to GDP after three decades implementation of various poverty reduction programs such as SAP is a cause for concern.

In Ghana, various poverty reduction programs were implemented using SAP. The first SAP phase became known as the Economic Recovery Program One (ERP-1). With a three-year life span (1983-1986), ERP-1 aimed to stabilize the economy and help, among other things, to increase productivity and to encourage exports while discouraging imports. Phase two (ERP-2) started in 1987 with the goal of consolidating the economic gains made in ERP-1 by reducing corruption.

In all, the massive corrupt practices adopted by African leaders since independence have proven to be one of the most important causes of poverty in the SSA. Corruption, as a broad term, covers a wide range of misuse of entrusted funds and power in the forms of theft, fraud, nepotism, and abuse of office for private gain. In Africa, these actions are considered as a significant business and a grave concern for many investors. Much of these practices negatively impact many governments through non-delivery of electoral promises, unfulfilled manifestos, and provision of poor services.

Besides, many corrupt practices in Africa are perpetrated through outright embezzlement of public funds by political leaders. For instance, Transparency International estimates that Mobutu Seseseko of Zaire and Nigeria's General Sani Abacha have embezzled up to USD5 billion from the treasury of their respective countries. In the same vein, Kenya's Mwai Kibaki's government, which ousted President Arap Moi in 2003, is investigating the former officials for embezzlement of USD1billion. Togo also fits in this category with their late President G. Eyadema and his corrupt practices (Azami, 2005). Indeed, several governments in Africa stand accused of plundering their own treasuries. Another example involves Angola's President Jose Eduardo dos Santos, under suspicion for stashing large sums of money into his personal bank accounts abroad. Finally, Equatorial Guinean President Teodoro Obiang calls oil revenues a "state secret" as his government was not prepared to account to the people the revenue generated from the oil resources their nation is blessed with, (Wrong, 2005).

In Ghana, after thirty years application of SAP, analysts believed that the long-term goals eluded the country. At the same time, the whole program came under question when one considered the national statistics figures on poverty. Again, the juxtaposition of the nation's riches versus the poverty came into play in this situation. Available statistics indicated that the SAP invariably led to an increase in GDP growth rate from negative $20 \%$ in 1983 to $4.1 \%$ per annum in 2009 (GDPC, 2010), repaired the structural imbalances, increased income per head by an average of $2 \%$, tripled the export goods production between 1986 and 1992, increased growth in the non-traditional export sector from $25 \%$ in 1983 to about $46 \%$ in 1990, and ensured a drop in annual inflation from $123 \%$ per annum in 1983 to about $10 \%$ in 2013 (GSS, 2014). At the same time, the agricultural sector continued to decrease in terms of GDP growth and total output. Hence, despite the achievements, poverty is still perceived to be on the increase in the rural areas of Ghana.

The reduction in GDP growth in the agricultural sector raises numerous questions such as: Is the declining agricultural contribution to GDP in some way linked to the rural poverty phenomenon since the bulk of agricultural production in Ghana takes place mainly in the rural areas? Or has SAP in general led to poverty reduction in the rural areas of Ghana?

When considering the Keta municipality in the Volta region of rural Ghana, three specific research questions emerge from the overarching queries:

1) What is the profile and severity of poverty and its distribution across the artisanal fishing communities in Ghana?

2) What is the level of poverty in the artisanal fishing communities in Ghana?

3) What is the impact of poverty reduction strategies in the artisanal fishing communities in Ghana?

To answer the research questions, the relevant literature review looks at the competing definitions of poverty and the artisanal fishing communities.

\section{Literature Review}

The combined effect of the "Trio-Crisis" in Africa, Colonialism (1960s), Cold War (1998), and Apartheid (1994), has been blamed for plunging the continent into poverty. When these socio-political times ended and new 
strategies were put into place, economists expected the poverty rates to lessen in Sub-Saharan Africa. The opposite happened: they continued to rise. This unforeseen circumstance concerned and worried economists when considering the agricultural potential coupled with the many poverty reduction strategies championed by the World Bank and the IMF during the last three decades.

Indeed, it is believed that SAP in most cases has induced growth and reduced poverty in those African countries where successfully implemented (World Bank 2000: Christiansen et al., 2001). Many consider Ghana one of these success cases. The country has experienced economic growth since 2000 with an average GDP growth rate of $7.2 \%$ as compared to the SSA's average growth rate of 5.7\% (IMF, 2012). Additional statistics show a different story.

Klasen (2003) indicated that in African countries which experienced a minimal reduction in poverty and economic growth, the growth had no linkage to SAP and its related macroeconomic policies. This fits Ghana's situation. The Ghana Living Standard Survey Six (GLSS 6) indicated that while poverty declined from 7.5\% percent from 2006 to 2013 in Ghana, the rural coastal communities continued to experience a $3.1 \%$ increase in poverty (Anderson and Obeng, 2016).

Nonetheless, the World Bank (1992), continued to tout the achievements of SAP. The global institution indicated that the middle-income countries that embarked on SAP enjoyed growth four percentage points higher than would otherwise have occurred and that the low-income countries had growth two percentage points higher. These studies concluded that adjustment lending also is associated with improved policies. However, results from a wide range of independent researchers prove otherwise with positive, zero, or negative effects of adjustment lending on growth (Killick et al., 1998). Also, recent studies (Przeworski and Vreeland, 2000; Barro and Lee, 2002) find a significantly negative effect of IMF lending on growth.

Despite these developments, the perception on the performance of adjustment operations remains mixed. By 2000, the failures of SAP in SSA were without doubt. Structural Adjustment Loans to various SSA countries that embarked upon specific programs with the IMF and the World Bank had to be repeated for many years under the SAP. Despite the repetition, the expected result was a dream. Various countries concluded that SAP has not helped the people in the region and not even the multiple lending under SAP could assist the countries in achieving the economics growth they long waited for.

Indeed, William Easterly (2003) demonstrated the failures of SAP in SSA when he used Probit regression analysis. He established that none of the top 20 recipients of repeated adjustment lending from the World Bank and the IMF under the SAP for 20 years (1980 to 2000) achieved reasonable growth.

The majority of these countries rendered poor by SAP are in SSA, a region noted for its optimal agricultural production. This insight emerged at a time when Channing Arndtl et al. (2010) found a statistically significant relationship between poverty reduction and agricultural productivity. For them, as agricultural productivity increased, poverty lessened. However, GLSS 6 indicated that household heads engaged in agriculture or fishing are more likely to be the poorest in Ghana. As a result, it is significant to note that decades of implementation of SAP in many Sub-Saharan African countries with comparative advantage in agricultural production actually resulted in poor economic performance by many.

This development led to the rejuvenation of the old debate about poverty reduction and gave rise to numerous articles. Many writers (Franz H and Boar G, 2011 and Tabisa W, 2013) focused on internal features of African countries such as ethno-linguistic fractionation, state structures, economic marginalisation, and demography. In fact, Sender (1999) also opposed the views of many economists on their stand about Africa's growth and development. He argued major progress had occurred on poverty reduction, but they failed to address the relative position of Africa within the world system.

Besides the World Bank and the IMF poverty reduction programmes, various governments in the SSA have identified agriculture as a tool for poverty reduction. Growth and development of a country driven largely by agriculture generates a larger welfare effect than non-agriculturally driven growth, especially for the poorest $20 \%$ of the population (World Bank 2007). Indeed, Mellor (2001) and Desai (2002) alluded to the fact that ultimate growth in agricultural productivity is vital for alleviating rural poverty in developing countries. In an agrarian economy, the overall growth and development in the agricultural sector has the potential to expand the economy and to alleviate poverty in the long run.

In theory, Mellor (1999) established that increase in agricultural output invariably increases income for poor rural farmers, leading to an increase in demand for goods and services produced by the non-farming rural poor. Hence, growth in agricultural productivity ultimately drives rural growth by promoting a pro-poor development 
programme as Thirtle et al. (2001) noted. A different scenario has been taking place in another agricultural section, fishing. This livelihood is contracting. Poor, rural fishing villages appear caught up in poverty and are resistant to improvement (Symes, 2015).

Irrigation systems comprise another agricultural component and have been a formal part of the poverty reduction processes. Several studies conducted in India demonstrated that farm irrigation management has a major role in terms of poverty reduction (Chamber 1988). Access to irrigation facilities is a key factor in this success. This action has resulted in a positive impact on poverty reduction by increasing agricultural production as a consequence of needed water making its way to the crops (Narayanamoorthy 2001; Fan et al. 1999; Shah and Singh 2002). Therefore, deliberate policies which aim at improving irrigation facilities automatically stimulate employment in the rural and urban non-farm sectors through forward and backward linkages (Hanmer and Naschold 2000). These actions produce a decrease in urban poverty by slowing migration to urban areas and lowering food prices (Mellor 1999).

Many studies, as shown, unequivocally have demonstrated that agricultural productivity growth as a result of poverty reduction strategies implemented by various countries had a positive impact on reducing poverty. However, a gap in the methodology and knowledge exists. The existing literature on rural poverty has deliberately failed to examine the incremental impact of each of the factor inputs on agricultural productivity growth as well as their marginal impact on poverty alleviation and rural income enhancement (WCD 5 2000).

Additionally, Byerlee et al. (2009) indicated that while Asian giants have seen steady growth in agricultural productivity and poverty reduction, rural-urban disparities and rural inequality have widened in the 1990s. In the same vein, Datt and Ravallion (1998) made it clear that an increase in agricultural productivity consequently contributes to lower food prices. However, the size of this effect is more difficult to estimate. The lower, relative food prices decreased absolute poverty in India, but did not in any way affect the distribution of poverty (Ibid.).)

As a result, considering the relative position of Africa as an agricultural-producing continent with abundant raw material, favourable climatic conditions, and abundant and rich natural resources coupled with the numerous World Bank and the IMF poverty reduction policies, a vital question invariably emerges: Have the various poverty reduction strategies made any positive economic impact on the lives of Africans in the rural areas where agricultural production is paramount?

\section{Research Method}

In an attempt to answer this primary question about the impact of the poverty reduction strategies in rural Africa, the authors chose Ghana as the country for exploration with a more specific focus on fishing villages in the rural part of the country. A structured interview questionnaire was utilized to collect data from the field. The information gleaned from the surveys provided the data to assess the level of poverty and the impact of poverty reduction strategies implemented in these Ghanaian artisanal fishing communities. The Greer-Thorbecke (FGT) Poverty Measures and the 2005/2006 Ghana Living Standard Survey five (GLSS -5) provided the methods to analyse the level and distribution of poverty across socio-demographic characteristics of the population using household annual expenditure on food and non-food items.

Ideally, it would have been helpful to conduct this project's survey along the entire coastline of Ghana. Unfortunately, that action would have been logistically difficult to do. Instead, out of the four coastal regions identified as poverty-endemic areas in Ghana, the Volta Region was selected through purposive sampling. In consultation with the Ghana Statistical Service (GSS), approximately 58 fishing communities in the Volta Region were identified with the majority located in the Keta Municipality as fishing villages with a degree of poverty. Systemic sampling method was employed to select 11 out of the 58 fishing communities for the sample.

From the 2010 Population and Housing Census figures, the boundaries of the chosen settlements (village) were defined. Amazingly, the research team realized that for the purposes of the National census in 2010, each village was sub-divided into Enumeration Areas (EA) with maps. What they did at this stage was to select one EA from the sampled communities using random sampling technique. In all, about eleven EA's were selected from different fishing villages.

This forms the basis for determining the sample size used in this study. Out of the eleven EA's identified and selected, about ten households from each were selected using systematic sampling method. At this stage, the research team, with permission from the traditional rulers and assembly members, numbered all the households in each EA after which number six were selected from a range of one to ten. Therefore, every sixth household in each EA was selected and enumerated until the ten households had been chosen, and a degree of randomness was preserved. In all, about 110 households were chosen using systematic sampling method. This number represents 
the actual sample size interviewed using structured interview questionnaires designed for the purpose.

The structured interview questionnaire consisted of seven main sections designed to solicit information on poverty in the research area. The survey was introduced to the five members of the research team. The questionnaire covered demographic characteristics of the household heads as well as household food consumption per day, week, month and year. These numbers determined the annual expenditure of each household.

In total, 110 individual household heads, both male and female, were sampled and interviewed in their communities, using structured interview questionnaires designed for the purpose. The researcher then used a Greer and Thorbecke - FGT poverty measure to determine the head count index- $(\mathrm{Po})$, poverty gap index- $(\mathrm{P} 1)$, and the income gap ratio.

The Head Count Index (Po) was used to measure the proportion of the population in the sample communities under study that fell below the upper poverty line. In 2010, the GSS estimated that to be 3,708,900.00 Cedis. The formula was mathematically denoted as:

$$
P_{o}=\frac{N_{p}}{N}
$$

$N p$ represented the number of the sample population below the poverty line; $\mathrm{N}$, represents the total sample population; and Po, the Head Count Index. Hence, Po can be written as:

$$
P_{0}=\frac{1}{N} \sum_{i=1}^{N} I\left(y_{i}<z\right)
$$

In this second formulate, $1\left(\mathrm{y}_{\mathrm{i}}<\mathrm{z}\right.$, $)$ was an indicator function taking positive values and zero when $\mathrm{y}_{\mathrm{i}}<\mathrm{z}$ was said to be true. Therefore, if the expenditure of the household (yi) was less than the poverty line denoted as (z), then the household would be classified as poor.

It is important to note that the Head Count Index did not indicate the level of poverty for each poor person. This limitation made it impossible to measure the Poverty Gap Index for any individual who had slipped below the poverty line. Based on these difficulties, the researcher used the Poverty Gap Index as a tool to indicate the extent to which the poor had fallen below the poverty line. In other words, the Poverty Gap Index was the extent to which an individual on average had fallen below the poverty line. That figure was expressed as a percentage of the poverty line. It gave a good indication of the depth of poverty since the statistic depended on the distance of the poor below the poverty line. The formula for this indicator is written as:

$$
\mathrm{G}_{\mathrm{i}}=\left(\mathrm{z}-\mathrm{y}_{\mathrm{i}}\right) . \mathrm{I}\left(\mathrm{y}_{\mathrm{i}}<\mathrm{z}\right)
$$

Gi denoted the poverty gap; $z$, the poverty line; and yi, the expenditure of the individuals. Therefore, using the index function, the Poverty Gap Index would be denoted as:

$$
P_{i}=\frac{1}{N} \sum_{i=1}^{N} \frac{G_{i}}{z}
$$

In sum, the following notations used in the study were derived from the above formulate: $P_{0}$ : represented the incidence of poverty, i.e., the proportion of the total number of households below the poverty line; and $P_{l}$, the Poverty Gap Index. $P_{I}$ was the measure of the intensity of poverty and was represented by the value of the FGT measure as defined in equation 4 . Furthermore, $P_{l} / P_{0}$ equaled the income-gap ratio, indicating the depth of poverty in the community. $C_{0}$ symbolized a group's contribution to the total poverty as revealed by $\mathrm{P}_{0}$, and $C_{l}$, a group's contribution to total poverty as a measure of the Poverty Gap Index, $P_{l}$. For comparative purposes, the researchers used the GLSS -5 2005/2006 upper poverty line of 3,708,900 Cedis and the FGT measure defined in the equations above to determine the $P_{0}, P_{l}$ and $P_{l} / P_{0}$ using the research data gathered from the field.

Table 1. Poverty indices for the Keta fishing community

\begin{tabular}{cccc}
\hline \multirow{2}{*}{ Poverty line in Ghana cedis $(\phi)$} & \multicolumn{3}{c}{ Poverty indices } \\
\cline { 2 - 4 } & $\mathrm{P}_{0}$ & $\mathrm{P}_{1}$ & $\mathrm{P}_{1} / \mathrm{P}_{0}$ \\
\hline $3,708,900$ & 33.0 & 8.9 & 0.27 \\
\hline
\end{tabular}

Field Data (2011)

Altogether, the incidence of poverty, $\mathrm{P}_{0}$, percentage of the population below the poverty line) was calculated at $33 \%$ 
for the upper poverty line of 3,708,900 as indicated in Table 1.0 below. That implied that all things being equal, $33 \%$ of the households in the Keta municipality would have an annual expenditure below the poverty line, thereby meeting this study's definition of "poor."

Also, using the poverty gap index, $P_{l}$ as stated in equation 1.4, the research data established that the level of resources needed to eliminate poverty in the sample area was $8.9 \%$. This differed from the GSS figure of $7.0 \%$ for all urban coastal localities. That is, on average, it will take a transfer of about $9.0 \%$ of economic resources to help individuals below the poverty line to eliminate poverty in the sample communities. As mentioned, the income gap ratio, $\left(P_{l} / P_{0}{ }^{\prime}\right)$, represented the ratio of the Poverty Gap Index and the incidence of poverty as defined above. From the table, $P_{l} / P_{0}$ can be interpreted to mean that those below the poverty line had an average level of living $27 \%$ below the poverty line.

\section{Presentation of Results and Discussion}

In this section, the results from the field study are discussed. Four factors stood out in the research and analysis: distribution of poverty by age of household heads, by level of education of household heads, by household size, and poverty distribution according to ownership of fishing gear.

\subsection{Distribution of Poverty by Age of Household Heads}

The age of the household heads turned out to be a significant factor in this study. Consequently, data collected in the sampled area was used to distribute poverty according to the age of the household heads. Table 2 below therefore presents the nature of the relationship between poverty and age of household heads in the fishing community of Keta. Ages of the household heads are divided into three parts: youth ( 35 years or less), the working class (36-50 years), and the older class (51 or older). This table also shows the distribution of the population among the age groups in the Keta fishing communities. Once again, the upper poverty line of 3,708,700 Cedis is used. From the table, the middle-aged group took the largest share of the population, $43.1 \%$, followed by the youth with $29.3 \%$. The older population comprised the smallest share of the population at $27.6 \%$.

In terms of the incidence of poverty $\left(\mathrm{P}_{0}\right)$ relative to the poverty line, the results showed that $40.7 \%$ of households headed by people in the middle age group of 36 to 50 were the poorest compared to the other age groups in the communities. This accounted for about $53 \%$ of the overall poverty in the community $\left(\mathrm{C}_{0}\right)$. The youngest and oldest groups followed respectively with incidences of poverty of $29 \%$ and $25 \%$.

The poverty gap index (P1) measures the extent to which individuals fall below the poverty line. Table 2 shows that the middle-age-headed households fell $11.2 \%$ below the poverty line as compared to the $7.1 \%$ and $7.0 \%$ recorded for both the youth and the old-age-group-headed households.

Table 2. Poverty distribution according to age of household-head

\begin{tabular}{lcccccc}
\hline \multicolumn{1}{c}{ Age range } & Popula-tion share & \multicolumn{3}{c}{ Poverty indices } & \multicolumn{2}{c}{ Contribution to poverty } \\
\cline { 3 - 7 } & & $\mathrm{P}_{0}$ & $\mathrm{P}_{1}$ & $\mathrm{P}_{1 /} \mathrm{P}_{0}$ & $\mathrm{C}_{0}$ & $\mathrm{C}_{1}$ \\
\hline Less than or equal to 35 years & 29.3 & 29.1 & 7.1 & 0.24 & 25.8 & 23.5 \\
36 to 50 years & 43.1 & 40.7 & 11.2 & 0.28 & 53.2 & 54.4 \\
Greater than or equal to 51 years & 27.7 & 25.0 & 7.0 & 0.28 & 21.0 & 22.1 \\
\hline Community & $\mathbf{1 0 0}$ & $\mathbf{3 3 . 0}$ & $\mathbf{8 . 9}$ & $\mathbf{0 . 2 7}$ & $\mathbf{1 0 0}$ & $\mathbf{1 0 0}$ \\
\hline Source: Field survey data (2011) & & & & & &
\end{tabular}

Of the total amount of resources needed to eradicate poverty in the fishing communities, households of the middle-aged group require $54.4 \%$; the youth, $23.5 \%$; and the households headed by the people above 50 years, $22.1 \%$ resources.

This outcome supports Kuznets' hypothetical invented U-shaped curve which hypotheses that the economic welfare of a household is expected to be closely associated with the age of the head of the household. In many developing countries, Kuznets observed that income per household showed a marked rise in the youth, reached a peak, and then dipped in old age (Kuznets, 1974). This becomes possible because of the retirement of individuals from active service at the age of 65 . Also, this scholar observed that the age of the household head has a close relationship with household size. As the age of the household head increases, more children are added to the family, it reaches a peak and falls. 
From the field data (Table 2), the first group, or the youth, experienced an increase in the incidence of poverty and the poverty gap index with the figures, $29.1 \%$ and $7.1 \%$, respectively. Both factors reached the peak in middle age at $40.7 \%$ (incidence of poverty) and $11 \%$ (poverty gap index). Following Kuznets' invented U-shape, the two indicators fell in the older-age groups, $25 \%$ and $7.1 \%$, respectively.

From the analysis above, it is clear that in the fishing communities of Keta, population growth has exceeded economic growth. This means that in an individual household, the rate at which income grows is far less than the rate of growth of the household's consumption. Additionally, the age of the household head rises along with a corresponding increase in the size of the family.

Many reasons explain the fall in poverty in the households headed by people of old age. One possibility is that more members of those households had grown enough to start work themselves and be contributing to the household's income, thereby closing the family's income-consumption deficit gap.

\subsection{Poverty Distribution according to the Level of Education of Household Heads}

The importance of education in poverty reduction cannot be over emphasized. Indeed, skills acquired through education are key in poverty reduction. Therefore, any effective poverty reduction policy must make conscious effort to invest in education. Poverty and underdevelopment are, in part, the consequences of lack of education (Wedgwood, 2005: UNESCO, 2002, 2003).

By 1990, the alleviation of poverty became the prime motive of many governments in Africa, including Ghana. The Ghanaian government identified education as key to poverty reduction. It has implemented various policies including Ghana Poverty Reduction Strategy 2002 - 2004 (GPRS I, February 2002), Education Sector Policy Review Report (ESPRR, August 2002), Education Sector Review (ESR, October 2002), Meeting the Challenges of Education in the 21st Century, Education for All (EFA, UNESCO, Dakar 2000), and the Education Strategic Plan (ESP) covering 2003-2015.

Table 3 below presents the distribution of poverty according to the level of education of the household head using the Ghana's upper poverty line 3,708,700 Cedis. From the table, it can be seen that over $60 \%$ of household heads have little or no formal education; $38.3 \%$, o no formal education; and nearly $23 \%$ attended primary school only. For the rest, 26.1\% attended Junior Secondary School (JSS)/Middle School; $10.1 \%$, Senior Secondary School (SSS); and $2.7 \%$, tertiary level (post-SSS).

Using the poverty line mentioned above, the incidence of poverty (that is, the number of people below the poverty line) was $60 \%$ among people with tertiary education in the fishing communities of Keta. In terms of the poverty gap index, people with tertiary education were $13.7 \%$ below the poverty line and required $0.23 \%$ resources to eliminate poverty.

Table 3. Poverty distribution according to level of education of household heads

\begin{tabular}{lcccccc}
\hline \multirow{2}{*}{ Level of education } & \multirow{2}{*}{ Population share } & \multicolumn{3}{c}{ Poverty indices } & \multicolumn{2}{c}{ Contribution to poverty of the community } \\
\cline { 2 - 7 } & & $\mathrm{P}_{0}$ & $\mathrm{P}_{1}$ & $\mathrm{P}_{1 /} \mathrm{P}_{0}$ & $\mathrm{C}_{0}$ & $\mathrm{C}_{1}$ \\
\hline No formal ed. & 38.3 & 37.5 & 11.1 & 0.296 & 43.5 & 48.1 \\
Primary school & 22.9 & 32.6 & 8.4 & 0.258 & 22.6 & 21.7 \\
JSS/middle school & 26.1 & 22.4 & 6.8 & 0.304 & 17.7 & 20.1 \\
SSS & 10.1 & 36.8 & 5.2 & 0.141 & 11.3 & 5.9 \\
Tertiary & 2.7 & 60.0 & 13.7 & 0.228 & 4.8 & 4.1 \\
\hline Community & $\mathbf{1 0 0}$ & $\mathbf{3 3 . 0}$ & $\mathbf{8 . 9}$ & $\mathbf{0 . 2 7 0}$ & $\mathbf{1 0 0}$ & $\mathbf{1 0 0}$ \\
\hline
\end{tabular}

Source: Field survey data (2011)

Similarly, people with a JSS/Middle School background experienced an incidence of poverty at $22.4 \%$ of poverty in comparison to people with other levels of education in the fishing communities of Keta. Persons with this level of education were $6.8 \%$ below the poverty line. As a result, they required about $0.30 \%$ of resources to move out of poverty.

From table 3, it can be observed that at the poverty line of 3,708,900 Cedis, over $60 \%$ of those who had tertiary-level education were thrown into poverty. Those in this category had attended teacher training colleges, 
polytechnics, or other post-senior secondary institutions. As contradictory as this result may seem, the high incidence of poverty of those who attained tertiary-level education was, however, downgraded by the relatively small proportion $(2.7 \%)$ of this group within the Keta fishing communities. Hence, its contribution to the total poverty of the communities was only $4.8 \%$

Furthermore, the high level of poverty among household heads with tertiary-level education makes an insignificant impact on the community because of their small number; that is, less than $3 \%$ of the whole community. In other words, efforts to reduce poverty among households in the community whose heads have higher levels of education will have an insignificant impact on the incidence of poverty in the community as a whole. This leaves the bulk of the population falling under the poverty line as those who have had little or no formal education.

Comparative analysis shows that a poor individual from a household headed by someone with tertiary-level education would require, on average, resources equivalent to $0.23 \%$ of the poverty line to escape poverty, as compared to $0.30 \%$ for an equally poor person from a household headed by someone with no formal education. Indeed, a careful study of the poverty index $\left(\mathrm{P}_{0},\right)$ in Table 3 reveals a fall in poverty from the least educated at $37.5 \%$ through primary school education at $32.6 \%$ to those educated at JSS/Middle School level at $22.4 \%$ and, thereafter, rising sharply. Thus, instead of a downward trend, a U-shaped relationship exists.

In addition, in terms of the groups' contribution to poverty in the communities, using the upper poverty line as shown in Table 3, the results showed a decreasing trend. Households with no formal education in the community had the highest share of poverty at $43.5 \%$, followed by those having primary-level education (22.6\%). These two groups alone had a total share of over $65 \%$ of the area's poverty. The rest shared the remaining $34 \%$ : JSS/Middle School (17.7\%), Senior Secondary School (11.3\%), and tertiary education (4.8\%). In terms of the total amount of resources needed to eradicate poverty from the entire fishing communities, the same decreasing trend can be seen. Households with heads without any formal education would require $48.1 \%$ of the total amount of resources needed to eliminate poverty. The corresponding shares of the total requirements of the other groups are: primary school (21.7\%); JSS/Middle School (20.1\%), SSS (5.9\%); and tertiary education (4.1\%).

\subsection{Poverty Distribution according to Household Size}

The size of a household is another important demographic variable that impacts poverty (Aniceto et al., 2005). Several studies, including those of Meenakshi, (2000), showed that larger households tend to have a greater incidence of poverty even though such households may have higher incomes. Although these larger families have, on average, a greater number of persons in the work force, expenses also remain high with several mouths to feed.

To avert this, the government of Ghana, in collaboration with World Health Organization (WHO), introduced many family planning policies such as subsidized condoms, injections, pills, free education on family planning, all aimed at reducing the number and spacing of children. To investigate if these subsidies made any impact on poverty reduction, the researcher collected data on household size and their incidence of poverty in the Keta fishing community as indicated using poverty line of 3,708,900 Cedis (see Table 4). Three household classifications were used: small (one to four members), medium-sized (five to six members), and large households (seven or more members).

Table 4. Poverty distribution according to household size

\begin{tabular}{|c|c|c|c|c|c|c|}
\hline \multirow[t]{2}{*}{ Household size } & \multirow[t]{2}{*}{ Population share } & \multicolumn{3}{|c|}{ Poverty indices } & \multicolumn{2}{|c|}{ Contribution to poverty of the community } \\
\hline & & $\mathrm{P}_{0}$ & $\mathrm{P}_{1}$ & $\mathrm{P}_{1 /} \mathrm{P}_{0}$ & $\mathrm{C}_{0}$ & $\mathrm{C}_{1}$ \\
\hline Small households (1-4) & 51.6 & 20.6 & 5.7 & 0.28 & 32.3 & 33.43 \\
\hline \multicolumn{7}{|l|}{ Medium-sized } \\
\hline households (5-6) & 25.5 & 47.9 & 12.3 & 0.26 & 37.1 & 35.31 \\
\hline \multicolumn{7}{|l|}{ Large households } \\
\hline ( 7 or more) & 22.9 & 44.2 & 12.1 & 0.27 & 30.6 & 31.26 \\
\hline Community & 100 & 33.0 & 8.9 & 0.27 & 100 & 100 \\
\hline
\end{tabular}

From the data, the incidence of poverty for small households is $20.6 \%$. This implies that $20.6 \%$ of the small-household population of the Keta fishing communities is thrown into poverty. The proportion increases to 
$47.9 \%$ for medium-sized households but then decreases to $44.2 \%$ for large households. This configuration appears to violate the normal trend and hypothesis put forth by the Ghanaian government and WHO.

Thus, medium-size households have the highest incidence of poverty at $47 . \%$ and small households have the least with $20.6 \%$. The same situation holds for the poverty gap index with figures for small, medium-sized, and large households as $5.7 \%, 12.3 \%$, and $12.1 \%$, respectively. This may be so because most large households have a substantial proportion of their members working. In addition, because the major occupation of the communities does not require any high level of formal education, people tend to start fishing and fish processing at an early age.

\subsection{Poverty Distribution according to Ownership of Fishing Gear}

Government corruption proves to be another critical factor in the context of poverty and poverty reduction in SSA.As a consequence, this research project also investigated the impact of ownership of fishing gear on poverty and its connection to government policies. Subsidising the prices of various fishing equipment for the fish farmers was a deliberate policy of the Ghanaian government to reduce poverty in these areas. Whether this has made any direct impact on poverty is yet to be known due to the perceptions that the good intention of the government has become a conduit for siphoning public funds through corrupt practices by the government appointees trusted with public funds. Ghanaians therefore believe that this development is worsening the poverty level of the rural folks as it makes the fishing equipment too expensive to afford by a rural fisher folk.

Currently, fishing gear in Keta is considered relatively expensive despite government intervention by introducing subsidies across the board. Consequently, owning a canoe, outboard engine, fishing net, or a permutation of the three, is prestigious in the fishing communities in Ghana. In order to compare poverty between those who own fishing gear and those who do not, the researcher presents poverty estimates in Table 5.

Table 5. Poverty Distribution by ownership of fishing gear by household heads

\begin{tabular}{lcccccc}
\hline \multirow{2}{*}{ Gear ownership } & \multirow{2}{*}{ Population share } & \multicolumn{3}{c}{ Poverty indices } & \multicolumn{2}{c}{ Contribution to poverty of the community } \\
\cline { 2 - 7 } & & $\mathrm{P}_{0}$ & $\mathrm{P}_{1}$ & $\mathrm{P}_{1 /} \mathrm{P}_{0}$ & $\mathrm{C}_{0}$ & $\mathrm{C}_{1}$ \\
\hline Own gear & 14.4 & 22.2 & 6.7 & 0.302 & 9.7 & 10.9 \\
Do not own gear & 85.6 & 34.8 & 9.2 & 0.264 & 90.3 & 89.1 \\
\hline Total & $\mathbf{1 0 0}$ & $\mathbf{3 3 . 0}$ & $\mathbf{8 . 9}$ & $\mathbf{0 . 2 7}$ & $\mathbf{1 0 0}$ & $\mathbf{1 0 0}$ \\
\hline Source: Field survey data (2011) & & & & &
\end{tabular}

The data indicates that, in the fishing communities of Keta, only about $14.4 \%$ of the total number of household heads owned any of the fishing gear despite the introduction of subsidies on fishing inputs. Out of that number, about $22.2 \%$ of fishing gear owners was poor, representing less than $10 \%$ of the poverty of the community. The incidence of poverty for non-gear-owning household heads was $34.8 \%$. The non-gear owning households represented about $90 \%$ of the poverty of the community. In terms of the poverty-gap index, the poor household heads who owned fishing gear were $6.7 \%$ below the poverty line. It would take a poor individual from a gear-owning household, on average, $0.3 \%$ of resources to move out of poverty. An individual from a non-gear-owning household was about $9.2 \%$ deep into poverty and would require resources equivalent to $0.264 \%$ to escape poverty. The non-gear-owning households collectively would need $89 \%$ of the total amount of resources required per year to eliminate poverty from the fishing.

These figures demonstrate that the adjustment loans and the policies, on their own, were not an effective method to reduce poverty in the fishing communities of Ghana. They needed good governance as well (Abbey, P. at al., 2016). For the past three decades, Ghana has followed the IFIs and has implemented their policies. They, however, have been unsuccessful in terms of poverty reduction in the fishing communities. Indeed, public sector corruption, including government appointees, has emerged as one of the basic problems affecting the distribution of the fishing gears to the fisher folks. For instance, equipment such as outboard motors do not always get to their rightful owners, (Chief fisherman, 2014)

Therefore, as these research figures have indicated, the IFIs and the government of Ghana would be better off re-directing the scarce economic resources towards the many programs that directly target the poor. This could take the form of income subsidies for the poor, infrastructure development targeted at these communities, improvement of access to credit facilities to enable the fisher folks to buy the equipment, subsidizing of fishing inputs, and improving access to market information for the fish farmers. 


\section{Conclusion}

One of the basic goals of every government is to reduce poverty and to ensure economic prosperity for its citizens. To achieve these goals, the government of Ghana, in collaboration with the International Financial Institutions such as the World Bank and the IMF, employ many poverty reduction strategies such as structural adjustment policies and structural adjustment lending as tools in poverty reduction.

Based on these reasons, this research project sought to examine the effect of various poverty reduction strategies employed by the government of Ghana and their effect on poverty after three decades of their implementation. This was done by providing answers to the research question on the profile and severity of poverty and its distribution in Ghana by focusing on artisanal fishing in the villages of Keta. These findings contradict the general view and the conclusions of many researchers that the various poverty reduction strategies adopted from the IMF and the World Bank by many countries in the SSA help reduce poverty (Rothchild, Donald, 1991).

In terms of age, it was clear that $43.1 \%$ of people in middle age were below the poverty line, as compared to the young adults at $29.1 \%$ and the elderly at $27.7 \%$, respectively. Also, in relation to education, the findings indicate that household heads with no formal education in the community had the highest share of poverty at $43.5 \%$, followed by those having primary-level education (22.6 \%). In all, household heads with JSS/Middle School background were the less poor in the community with $17.7 \%$ share of poverty. This was followed by Senior Secondary School (11.3\%), and tertiary education (4.8\%).

This finding has confirms the views that education helps in poverty reduction (Wedgwood, 2005: UNESCO, 2003) since many government workers are educated.

In all, the results from the field indicate a three decades' spectacular failure of poverty reduction policies implemented in the sample area. Therefore, it is incumbent on the government of Ghana, Non-Governmental Organizations, and the World Bank and its affiliates to endeavor to reduce the increasing poverty by providing the needed fishing equipment to various household heads since people who own fishing gear have a higher percentage of reducing poverty in the research area. Also, education is identified as one of the parameters that can aid poverty reduction. When the household heads are educated to the secondary school level, their level of poverty reduces.

Additionally, family size plays a vital role in poverty reduction. The government needs to embark on family planning education in the rural areas. As this study demonstrates, households with a smaller family size were more likely to be out of poverty than families with more members which resulted in more mouths to feed. When these things are done, it will enable various household heads in the fishing industry to reduce poverty. These actions will go a long way to eliminate the huge gap between Ghana's resource rich land and the reality of poverty. They also will help Ghana to achieve the Millennium Development Goals (MDG) as set out by the United Nations with the aim to create a poverty-free world.

\section{References}

Abbey, P., Tomlinson, P. R., \& Branston, J. R. (2016). Perceptions of Governance and Social Capital in Ghana's Cocoa Industry. Journal of Rural Studies, 44, 153-163. https://doi.org/10.1016/j.jrurstud.2016.01.015

Akerele, D., Momoh, S., Adewuyi, S. A., Phillip, B. B., \& Ashaolu, O. F. (2012). Socioeconomic determinants of poverty among urban households in South-West Nigeria. International Journal of Social Economics, 39(3), 168-181. https://doi.org/10.1108/03068291211199341

Anderson, A. R., \& Gaddefors, J. (2016). Entrepreneurship as Community Phenomenon; reconnecting meanings and place. International Journal of Entrepreneurial Small Business, 28(4). 504-518. https://doi.org/10.1504/IJESB.2016.077576

Aniceto, C., \& Orbeta, Jr. (2005, June). Poverty, Vulnerability and Family Size; Evidence from Philippines: ADB Institute Discussion Paper No.9.

Arndt, C., Garcia, A., Tarp, F., \& Thurlow, J. (2010). Poverty Reduction and Economic Structure, Comparative Path Analysis for Mozambique and Vietnam, Working Paper No. 2010/122.

Arnon Bar -On. (1997). Assessing Sub - Saharan Africa's Structural Adjustment Programmes: The need for More Qualitative Measures. Journal of Social Development in Africa, 12(1), 15-27.

Boafo-Arthur, K. (1999, September). Ghana: Structural Adjustment, Democratization, and Politics of Continuity. African Studies Review, 42(2). https://doi.org/10.2307/525364

Chambers, R. (1988). managing canal irrigation: Practical analysis from South Asia. New Delhi: Oxford and IBH Publishing Co. Pvt.Ltd. 
Domfeh, K. A., \& Bawole, J. N. (2011). Ensuring Effective Local Engagement in Poverty Reduction in West Africa. International Journal of Politics and Good Governance, 2(2).

Economic Commission for Africa. (2003). An Integrated ICT-Led Socio-Economic Development Policy and Plan Development Framework for Ghana.

European Commission. (2004). Joint report by the commission and the council on social inclusion, no 650/04 SOC 79 ECOFIN 55 EDUC 34 SAN 31 / COR, Brussels, 5, March, 2004.

Fosu, A. K. (2000). The International Dimension of African Economic Growth: CID Working Paper No. 34, Centre for International Development at Harvard University.

Ghana Statistical Service, (GSS). (2007). Ghana Living Standards Survey, Report of the Fifth Round (GLSS5) Accra, Ghana.

Ghana Statistical Service. (2012). Ghana's economic performance in 2011.

Haakosen, J. M. (1988). Socio-Economic Aspects of Ghana's Canoe Fisheries. In Resent Development of the Artisanal Fisheries in Ghana. IDAF/WP/21, IDAF Project (FAO) Cotonou, Benin.

Heidhues, F., \& Obare, G. (2011). lessons from Structural Adjustment Programmes and their effect in Africa. Quarterly journal of International Agriculture, (1), 55-64.

International Monetary Fund -IMF. (2012). World Economic Outlook. Growth Resuming, Dangers Remain. International Monetary Fund Publication Services, Washington DC.

Jorion, P. (1988). Going out or staying home: Seasonal movements and migration strategies among Xwla and Anlo-Ewe fishermen. MAST, 1(2), 129-155.

Klasen, S. (2003). what can Africa Learn from Asian Development Success and Failures. Review of Income and Wealth, 49(3), 441-451. https://doi.org/10.1111/1475-4991.00098

Klugman, J., Rodriguez, F., \& Choi, H.-J. (2011). The Human Development Index 2010: New Controversies, Old Critiques, United Nation Development Programme, Human Development Report Research Paper, 2011/01.

Koranteng, K. A., \& Pauly, D. (2004). Long-term trends in demersal fishery resources of Ghana in response to fishing pressure. In M. Palomares, \& D. Pauly (Eds.), West African marine ecosystems: models and fisheries impacts. Vancouver: UBC, Fisheries Centre, Fisheries Centre Research Reports 12 (7).

Lynge, N. (2009). Global Relative Poverty. IMF working Paper, WP/09/93.

Meenakshi, J. V., \& Ray, R. (2000). Impact of Household Size and Family Composition on Poverty in Rural India. JEL Classification: C81, D63, I32, J18, o57.

Ministry of Food and Agriculture (MOFA). (2011). Agriculture in Ghana, Facts and figures, (2010), Statistical Research and information Directorate, (SRID).

Moss, T., \& Majerowicz, S. (2012). No Longer Poor: Ghana's New Income Status and Implications of Graduation from IDA. CGD Working Paper 300, Washington, D.C.: Center for Global Development. Retrieved from http://www.cgdev.org/content/publications/detail/1426321

Nukunya, G. K. (1989). The Anlo-Ewe and Full-Time Maritime Fishing: Another View. Maritime Anthropological Studies, 2(2), 156.

Poulton, C., Kydd, J., \& Dorward, A. (2006). Overcoming market constrains to pro - poor agricultural growth in sub Saharan Africa. Development Policy Review, 24(3), 243. https://doi.org/10.1111/j.1467-7679.2006.00324.x

Rothchild, D. (1991). Ghana and Structural Adjustment; an over view. In D. Rothchild (Ed.), Ghana; the political economy of recovery. Lynne Reinner publishes London.

Sachs, J. (2005). The End of Poverty: how can we make it happen in our lifetime? London: Penguin Books.

Sachs, J., \& Warner, A. (1997). Sources of Slow Growth in African Economies. Journal of African Economies, 6(3). https://doi.org/10.1093/oxfordjournals.jae.a020932

Sen, A. (2000). Social Exclusion: Concept, Application and Scrutiny, Social Development Paper 1 (Manila; Office of Environment and Social Development, Esian Development Bank).

Sen, A. K. (1983). Development: Which Way Now? EJ 93: 745-62; reprinted in his book Resources, Values and Development, Cambridge, MA: Harvard University Press, 1984, pp. 485- 508. 
Sender, J. (1999). Africa's Economic Performance: Limitations of the Current consensus. Journal of economic performance, 3(13). https://doi.org/10.1257/jep.13.3.89

Symes, D., Phillipson, J., \& Salmi, P. (2015). Europe's Coastal Fisheries; instability and the impacts of fisheries policy. Sociol. Rural, 55(3). https://doi.org/10.1111/soru.12096

Townsend, P. (1979). Poverty in the United Kingdom: A Survey of Household Resources and Standard of Living. University of California Press, Berkley.

United Nations Development Programme (UNDP). (2004). Human Development Report, Cultural liberty in Todays Diverse world, Journal of Human Development: Alternative Economic in Action, Carfax Publishing, Teylor and Francis Inc. Customer Services Department, 325 Chestnut Street, Philadelphia, US.

United Nations Development Programme (UNDP). (2005). Human Development Report, International cooperation at a crossroads: Aid, trade and security in an unequal world.

United Nations Development Programme (UNDP). (2013). the Rise of the South: Human Progress in a Diverse World.

Walwema, T. (2013). Adjusting Structural Adjustment: The role of the Structural Adjustment Program in Africa's Development.

Wedgwood, R. (2005). Education and Poverty Reduction in Tanzania. UKFIET. Oxford Conference on Education and Development. September.

Zamfir, L. (2016). Africa's Economic Growth, taking off or slowing down? European Parliamentary Research Services (EPRS).

\section{Copyrights}

Copyright for this article is retained by the author(s), with first publication rights granted to the journal.

This is an open-access article distributed under the terms and conditions of the Creative Commons Attribution license (http://creativecommons.org/licenses/by/4.0/). 